\title{
Predictive ability of the feeding system in Iberian pig by means of several analytical methods
}

\author{
By J.M. García Casco ${ }^{a, *}$, M. Muñoz ${ }^{a}$ and E. González ${ }^{b}$ \\ ${ }^{a}$ Centro de I+D en Cerdo Ibérico - INIA, Ctra. EX-101 km 4,7, 06300 Zafra (Badajoz) \\ ${ }^{\mathrm{b}}$ Animal Production, Escuela de Ingenierías Agrarias, Universidad de Extremadura, Ctra. de Cáceres s/n, \\ 06007 Badajoz \\ * Corresponding author: garcia.juan@inia.es
}

\section{RESUMEN}

Resultados de predicción de varios métodos analíticos propuestos para determinar la alimentación recibida en la etapa de cebo por cerdos Ibéricos

Se ha contrastado la fiabilidad de varios métodos analíticos para determinar el tipo de alimentación recibida durante el cebo por cerdos lbéricos a partir de muestras de tejido adiposo subcutáneo, procedentes de 38 partidas de cerdos de tres campañas de montanera. Las muestras correspondieron con las categorías de alimentación contempladas en la Norma de Calidad: 251 fueron de bellota, 164 de recebo, 197 de campo y 137 de cebo. Los métodos contrastados han sido ácidos grasos, NIR, alfa y gamma tocoferol, sensor químico, triacilglicéridos, isótopos estables y neofitadieno. Los distintos laboratorios recibieron las muestras sin información sobre el tipo de alimentación y remitieron sus predicciones respecto a las categorías previamente mencionadas. Los resultados obtenidos mostraron un elevado porcentaje de aciertos de los métodos cuando la alimentación se corresponde con las categorías extremas (bellota y cebo), sin embargo existía una dificultad en clasificar correctamente las muestras de cerdos de alimentación mixta con bellota y pienso (recebo) y confusión de algunos métodos cuando los cerdos son cebados con piensos que incluyen grasas vegetales con altos niveles de ácido oleico. Aunque la consideración de sólo dos categorías (cebo/campo y recebo/bellota) eleva el nivel de acierto por encima del $90 \%$ en algunos métodos, la combinación de dos o tres técnicas para muestras problemáticas permitiría diferenciar las cuatro categorías con el mismo porcentaje de éxito.

PALABRAS CLAVE: Cerdos Ibéricos - Métodos analíticos - Norma de Calidad - Predicción - Tipos de alimentación.

\section{SUMMARY}

Predictive ability of the feeding system in Iberian pig by means of several analytical methods

The reliability of several analytical methods proposed to predict the feeding system received by lberian pigs during the fattening period has been contrasted. Samples of subcutaneous adipose tissue were analyzed from 38 batches of pigs fattened in three seasons of montanera (acorn and pastures feeding). They corresponded to the four categories described in the Quality Standard for Iberian pig products: 251 samples of bellota, 164 of recebo, 197 of cebo de campo and 137 of cebo. To perform the study, the following analytical methods were used: fatty acid quantification, NIR, alpha and gamma tocopherol, chemical sensor, triacilglycerides, stable isotopes and neophytadiene. The laboratories received the samples without any information about the fattening system to which they belonged and remitted their predictions with respect to the above categories. The results showed a high percentage of accurate predictions of the methods when the fattening type corresponds to the extreme categories (bellota and cebo), however, the methods had difficulty in discerning between samples from a mixed feeding regime with acorn and feed (recebo) and problems when pigs are fattened with compound feeds including vegetable fats with high levels of oleic acid. Although a simplification into only two categories (cebo/campo and recebo/bellota) results in a success rate higher than $90 \%$ for some methods, the combination of two or three techniques with problematic samples allows for differentiating among the four categories with the same accuracy.

KEY-WORDS: Analytical methods - Feeding categories - Iberian pigs Prediction - Quality Standard.

\section{INTRODUCTION}

For centuries, the Iberian pig has maximized the natural resources of the Dehesa ecosystem especially by montanera, a feeding system in which the Iberian pigs eat acorns and grass from these Mediterranean holm oak and cork woodlands from November to March. This perfect acclimatization has led the conservation of the Dehesa which is threatened by several determinants arising from industrial development. The products derived from these animals have high quality because this traditional feeding type lends special physicochemical characteristics to them. In fact, the high costs of the extensive production and Dehesa management are economically justified by the high price of their derivatives.

In the last 30 years the increased demand for Iberian pork products has led to a rise in production which is non-parallel with the natural resources available. The Dehesa forest cannot support the density of animals that the market demands and the Iberian pigs are feeding with grains and compound feeds. As a result, the derivatives have different characteristics than those that come from 
pigs that carried out their final fattening according to montanera and the prices of the products are lower. This kind of intensive production was $80 \%$ of the total in 2011 [Electronic Record of the Iberian pig, "Ministerio de Agricultura, Alimentación y Medio Ambiente" (MAGRAMA)].

Since Iberian pigs were fed with products different from those of the Dehesa, different characteristics were observed both in meat and fat content. In particular, marbling, iodine index, melting temperature or fatty acid composition of backfat were used to distinguish among the different feeding types (Flores et al., 1988). In the late 80's, it was necessary to establish an analytical method that discriminates among products of animals feeding through a montanera system and those feeding with compound feeds. From the montanera season 1988/89 and following, the determination of palmitic, stearic, oleic and linoleic backfat fatty acids was chosen among the mentioned methods as the reference analytical method in the contracts of sale between breeders and producers (BOE, 1998).

However, backfat fatty acid composition is easily modified by adding particular components to the compound feeds; therefore, the composition of these four fatty acids is very similar to those feeding by montanera system and the power of the analytical method to distinguish among the categories decreases.

Despite this, the first Quality Standard Spanish legislation (BOE, 2001) established backfat fatty acid quantification as a complementary method to the farm inspection in order to label the products depending on the feeding type of the pig batches in their final fattening. Later, a protocol regulating the sampling-drawing procedure from the carcasses and the analytical method was developed (BOE, 2004).

From a legal point of view, the Quality Standard currently in force (BOE, 2007) established four categories in function of their final fattening phase feeding type: bellota or montanera, recebo, cebo de campo and cebo (Figure 1). The Quality Standard also binds a specific labeling for each category. This new Quality Standard was proposed with the purpose of amending deficiencies; however, it removed the analytical method and did not replace it with any other. Nowadays, an objective analytical method is not applied and the responsibility for discerning among the different feeding systems is left to the farm inspection during the montanera season and the estimations of the acorn production and the increase in animal weight.

In addition to the proposal of fatty acid quantification as an analytical control method, some authors suggested the quantification of any other components or the analyses of physicochemical characteristics to distinguish among the different feeding types, especially effective for the cebo category.

In 2008, a Project funded by the "Instituto Nacional de Investigación Agraria y Alimentaria" (INIA) and the MAGRAMA which contrasted the validity of the different analytical methods developed by the mentioned research groups was organized. The objective of the current study consisted of presenting the prediction results of each analytical method to assign the animals according to the feeding type received during the final fattening stage, using back fat samples of Iberian pigs collected in three different montanera seasons.

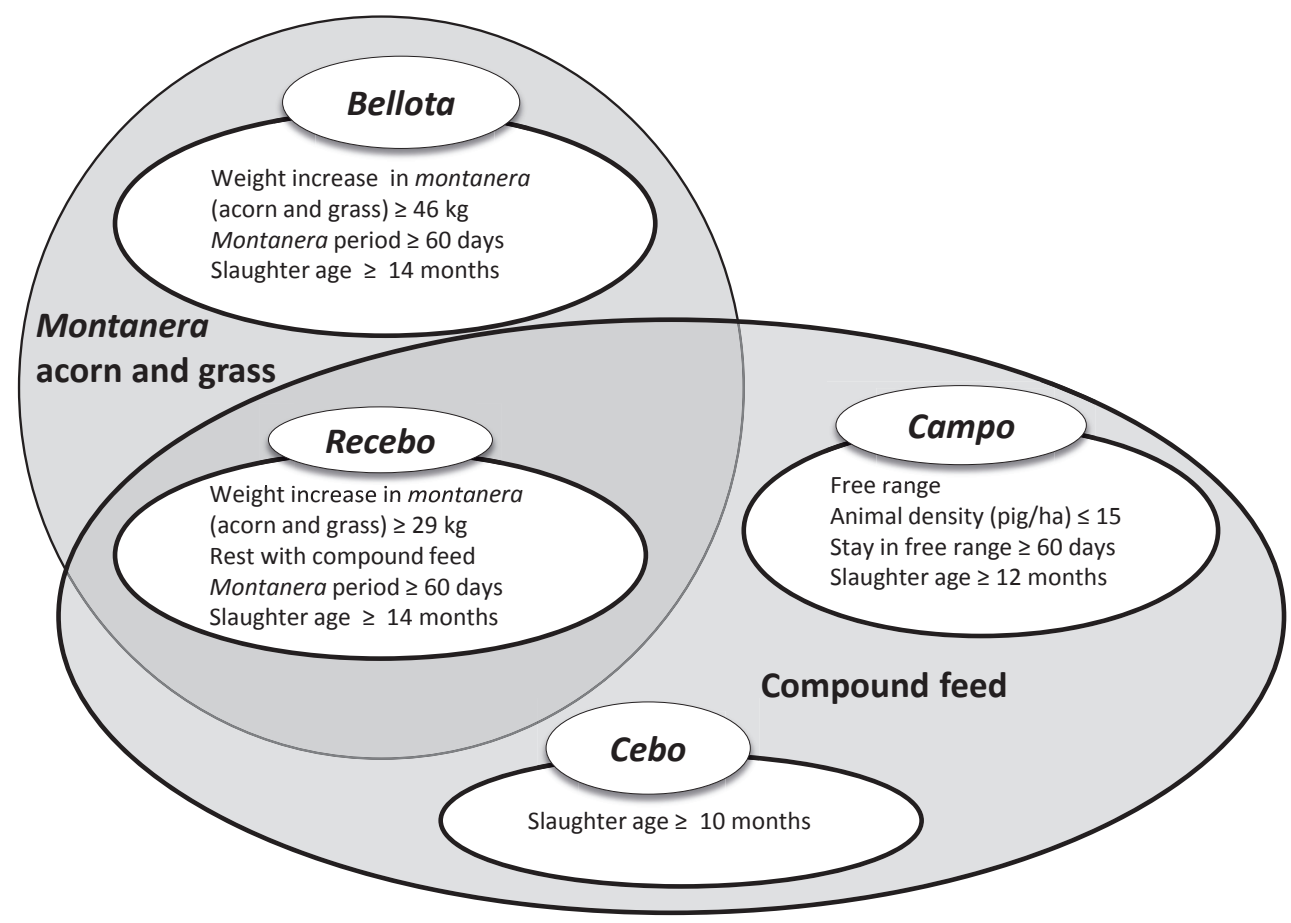

Figure 1

Schematic representation of the feeding categories included in the Quality Standard Spanish legislation (BOE, 2007). 


\section{MATERIALS AND METHODS}

\subsection{Animals}

Pigs were classified into different groups according to the four Quality Standard Spanish legislation categories (bellota, recebo, campo and cebo). Bellota and recebo pigs eat acorns during the montanera season in which acorns are mature. This period starts in November and finishes in March. All animals were slaughtered over three consecutive montanera seasons (2008/2009, 2009/2010 and 2010/2011) despite the fact that campo and cebo animals can be fattened throughout the year. Samples of back fat (300 $\mathrm{g}$ approx.) were taken close to the rump after slaughter.

Tables 1, 2 and 3 show a brief description of the pigs controlled in the three seasons. Each batch corresponds to a group of pigs with identical management and feeding regime, slaughtered on the same date at the same slaughterhouse. All pigs were Iberian unless specified otherwise in the cited tables. The high fat compound feeds have vegetable fats with high levels of oleic fatty acids. Table 4 shows the total number of analyzed samples according to the Quality Standard categories.

The study of the first montanera season focused on the analysis of the animals fed on acorns from different geographic locations, while the second montanera season was especially designed to consider the recebo animals and the batches of pigs fed with high fat compound feeds in order to obtain fatty acid profiles similar to those found in bellota pigs. In the third montanera season the number of groups was increased and diversified even though the number of samples analyzed in each group was lower.

\subsection{Analytical methods}

The samples were analyzed with different analytical methods which were carried out by different research groups. They received the samples without any additional information about the feeding type. After, the research groups sent the results and predictions to the project coordinator. The methods employed in the current study and the research groups who participated in the project were:

1. Quantification of methyl esters of palmitic, stearic, oleic and linoleic fatty acids (FA) by gas chromatography (Flores et al., 1988; Osorio et al., 1991; Ordóñez et al., 1996). Instituto Tecnológico Agroalimentario, Junta de Extremadura.

2. Near infrared spectroscopy (NIR) (De Pedro et al., 1995; García-Olmo et al., 2009). Escuela Superior Ingenieros Agrónomos, Universidad de Córdoba.

3. Quantification of alpha and gamma tocopherol (TOC) by high-performance liquid chromatography (Rey et al., 1998; Rey et al., 2006). Facultad de Veterinarias, Universidad Complutense de Madrid.

4. Chemometric analysis of chemical spectral fingerprint of volatile compounds by chemical

Table 1

Description and number of samples of the batch analyzed in the season of 2008/09

\begin{tabular}{|c|c|c|c|c|}
\hline Category & Code & Location & Description & $\mathbf{N}$ \\
\hline Cebo & CE08-1 & $\begin{array}{l}\text { Fuente Obejuna } \\
\text { (Cordoba) }\end{array}$ & $\begin{array}{l}\text { F1 with Duroc } \\
\text { Intensive feed } \\
\text { Not high fat feeds }\end{array}$ & 32 \\
\hline Campo & CA08-1 & $\begin{array}{l}\text { Olivenza } \\
\text { (Badajoz) }\end{array}$ & $\begin{array}{l}\text { Very low pasture intake } \\
\text { High fat feeds }\end{array}$ & 13 \\
\hline Campo & CA08-2 & $\begin{array}{l}\text { Valdesequera } \\
\text { (Badajoz) }\end{array}$ & $\begin{array}{l}\text { Pasture intake in big enclosure without oaks } \\
\text { Not high fat feeds }\end{array}$ & 23 \\
\hline Campo & CA08-3 & $\begin{array}{l}\text { Valdesequera } \\
\text { (Badajoz) }\end{array}$ & $\begin{array}{l}\text { Pasture intake in big enclosure with oaks } \\
\text { Weight gain with acorn below recebo category }(29 \mathrm{~kg}) \\
\text { Not high fat feeds }\end{array}$ & 39 \\
\hline Recebo & R08-1 & $\begin{array}{l}\text { Torrecampo } \\
\text { (Cordoba) }\end{array}$ & $\begin{array}{l}\text { Final shortage of acorn } \\
\text { Supply with feed to finish fattening period } \\
\text { Weight gain with acorn very high ( } 44 \mathrm{~kg})\end{array}$ & 28 \\
\hline Recebo & R08-2 & $\begin{array}{l}\text { Valdesequera } \\
\text { (Badajoz) }\end{array}$ & $\begin{array}{l}\text { Acorn season of only } 60 \text { days } \\
\text { Weight gain with acorn below the bellota category }(40 \mathrm{~kg}) \\
\text { No feed after acorn }\end{array}$ & 12 \\
\hline Bellota & B08-1 & $\begin{array}{l}\text { Ciudad Rodrigo } \\
\text { (Salamanca) }\end{array}$ & $\begin{array}{l}\text { Castrate sows yet before fattening period } \\
\text { Low slaughter weight }(149 \mathrm{~kg})\end{array}$ & 29 \\
\hline Bellota & B08-2 & $\begin{array}{l}\text { Cabeza la Vaca } \\
\text { (Badajoz) }\end{array}$ & $\begin{array}{l}\text { Very extensive management in mountain geography } \\
\text { Weight gain with acorn very high ( }>46 \mathrm{~kg})\end{array}$ & 32 \\
\hline
\end{tabular}


Table 2

Description and number of samples of the batch analyzed in the season of 2009/10

\begin{tabular}{|c|c|c|c|c|}
\hline Category & Code & Location & Description & $\mathbf{N}$ \\
\hline Cebo & CE09-1 & $\begin{array}{l}\text { Alburquerque } \\
\text { (Badajoz) }\end{array}$ & $\begin{array}{l}\text { F1 with Duroc } \\
\text { Intensive feed } \\
\text { Liquid not high fat feeds }\end{array}$ & 25 \\
\hline Campo & CA09-1 & $\begin{array}{l}\text { Olivenza } \\
\text { (Badajoz) }\end{array}$ & $\begin{array}{l}\text { Low pasture intake } \\
\text { High fat feeds }\end{array}$ & 25 \\
\hline Campo & CA09-2 & $\begin{array}{l}\text { Valdesequera } \\
\text { (Badajoz) }\end{array}$ & $\begin{array}{l}\text { Pasture intake in big enclosure without oaks } \\
\text { Not high fat feeds }\end{array}$ & 25 \\
\hline Campo & CAO93 & $\begin{array}{l}\text { Valdesequera } \\
\text { (Badajoz) }\end{array}$ & $\begin{array}{l}\text { Pasture intake in big enclosure without oaks } \\
\text { High fat feeds }\end{array}$ & 25 \\
\hline Recebo & R09-1 & $\begin{array}{l}\text { Valdesequera } \\
\text { (Badajoz) }\end{array}$ & $\begin{array}{l}\text { Weight gain with acorn above minimum of Quality } \\
\text { Standard }(30,5 \mathrm{~kg})\end{array}$ & 25 \\
\hline Recebo & R09-2 & $\begin{array}{l}\text { Valdesequera } \\
\text { (Badajoz) }\end{array}$ & $\begin{array}{l}\text { Simultaneous acorn plus feed } \\
\text { Weight gain of } 55 \mathrm{~kg} \\
\text { Fattening system out of the Quality Standard }\end{array}$ & 25 \\
\hline Bellota & B09-1 & $\begin{array}{l}\text { Fuente Obejuna } \\
\text { (Cordoba) }\end{array}$ & Weight gain above minimum of Quality Standard $(57,5 \mathrm{~kg})$ & 25 \\
\hline Bellota & B09-2 & $\begin{array}{l}\text { Valdesequera } \\
\text { (Badajoz) }\end{array}$ & $\begin{array}{l}\text { Weight gain below Quality Standard }(41 \mathrm{~kg}) \\
\text { Preserves bellota category }\end{array}$ & 30 \\
\hline
\end{tabular}

sensor (SQ) based on gas chromatography (Carrasco et al., 2007). Instituto de Ciencia y Tecnología de Alimentos y Nutrición, CSIC Madrid.

5. Analysis of triglyceride fraction by gas chromatography (TRIG) (Gamero-Pasadas et al., 2006; Vieira-Alcaide et al., 2008). Instituto de la Grasa, CSIC Sevilla.

6. Quantification of stable isotopes ratio by gas chromatography with combustion cell and mass spectroscopy (ISOT) (González Martín et al., 2001; Recio, 2007). Facultad de Ciencias, Universidad de Salamanca.

7. Quantification of neophytadiene (branched hydrocarbon) by gas chromatography (NEOP) (Tejeda et al., 1999). Escuela de Ingenierías Agrarias, Universidad de Extremadura.

\subsection{Statistical analyses}

The results are shown as the percentage of correct predictions of the analytical methods in each batch and/or in each Quality Standard category. The total of successes within the Quality Standard category is calculated from the total number of individuals.

\section{RESULTS}

\section{1. $2008 / 09$ and $2009 / 10$ seasons}

The prediction results of the analytical methods carried out during the two first seasons are shown in Tables 5 and 6 . These results are expressed as the percentage of correct predictions in each controlled pig batch and each feeding type category. Table 5 details the degree of accuracy in three categories (cebo/campo, recebo and bellota) since most of the methods in the first season did not differentiate among these categories. The quantification of neophytadiene is the exception because the base of this method is the use of grass intake as an indicator of extensive production versus cebo pigs (Tejeda et al., 1999). Table 6 also shows the prediction of four categories performed by the other three methods (TOC, SQ and TRIG)

The results of the first season show a good general prediction for the bellota batches (B08-1 and B08-2). The prediction level of the cebo batch (CE8-1), in which the pigs did not exploit other resources like grass and did not consume high fat compound feed, achieved $100 \%$ in most of the methods (except a 93\% with the SQ).

The influence of the high fat or not high fat compound feed was very relevant in the campo pigs. Samples from animals feeding with high fat compound feeds were correctly classified (C0802). However, when the campo pigs were fed using compound feeds with a high content in oleic fatty acid (CA08-1) there was no method with more than $50 \%$ of success, even four of them classified all the samples as recebo or bellota. Neophytadiene (92\% success) correctly classified the samples because this method detected a lower intake of grass than the usual in the categories of recebo and bellota.

The quantity and moment of acorn intake was decisive in the classification of the campo (CA08-3) and recebo batches (R08-1 and R082). Methods trend to classify CA08-3 as recebo, despite it belonging to a category in which acorn intake was not usual. Otherwise, R08-1 had a high weight gain with acorn and pasture (44 kg) and 
Table 3

Description and number of samples of the batch analyzed in the season of 2010/11

\begin{tabular}{|c|c|c|c|c|}
\hline Category & Code & Location & Description & $\mathbf{N}$ \\
\hline Cebo & $\begin{array}{l}\text { CE10-1 } \\
\text { CE10-2 }\end{array}$ & $\begin{array}{l}\text { Valdesequera } \\
\text { (Badajoz) }\end{array}$ & $\begin{array}{l}\text { Two batches } \\
\text { High fat feeds } \\
\text { Different in the level of protein }\end{array}$ & $8+10$ \\
\hline Cebo & CE10-3 & $\begin{array}{l}\text { Salvaleón } \\
\text { (Badajoz) }\end{array}$ & $\begin{array}{l}\text { F1 with Duroc } \\
\text { Intensive feed } \\
\text { Not high fat feeds }\end{array}$ & 15 \\
\hline Cebo & CE10-4 & $\begin{array}{l}\text { Topas } \\
\text { (Salamanca) }\end{array}$ & $\begin{array}{l}\text { F1 with Duroc } \\
\text { High fat feeds } \\
\text { Pasture intake in small enclosure }\end{array}$ & 25 \\
\hline Cebo & CE10-5 & $\begin{array}{l}\text { FuenteObejuna } \\
\text { (Córdoba) }\end{array}$ & $\begin{array}{l}\text { F1 with Duroc } \\
\text { Intensive feed } \\
\text { Not high fat feeds }\end{array}$ & 22 \\
\hline Campo & CA10-1 & $\begin{array}{l}\text { Fuente de Cantos } \\
\text { (Badajoz) }\end{array}$ & $\begin{array}{l}\text { F1 with Duroc } \\
\text { Pasture intake in big enclosure with oaks } \\
\text { Very low acorn intake } \\
\text { High fat feeds }\end{array}$ & 25 \\
\hline Campo & CA10-2 & $\begin{array}{l}\text { Olivenza } \\
\text { (Badajoz) }\end{array}$ & $\begin{array}{l}\text { Pasture intake } \\
\text { High fat feeds }\end{array}$ & 22 \\
\hline Recebo & $\mathrm{R} 10-1$ & $\begin{array}{l}\text { Valdesequera } \\
\text { (Badajoz) }\end{array}$ & $\begin{array}{l}\text { Acorn season of } 30 \text { days } \\
\text { Weight gain with acorn of } 29 \mathrm{~kg} \\
\text { Stay in montanera below minimum of Quality Standard } \\
\text { No compound feeds after acorn }\end{array}$ & 8 \\
\hline Recebo & R10-2 & $\begin{array}{l}\text { Cabeza la Vaca } \\
\text { (Badajoz) }\end{array}$ & $\begin{array}{l}\text { Extensive management in oak woodland with low intake } \\
\text { of acorn } \\
\text { Supply with waste products from olive oil industry }\end{array}$ & 11 \\
\hline Recebo & R10-3 & $\begin{array}{l}\text { Fuente de Cantos } \\
\text { (Badajoz) }\end{array}$ & $\begin{array}{l}\text { Weight gain with acorn in agreement with Quality } \\
\text { Standard }\end{array}$ & 20 \\
\hline Recebo & $\begin{array}{l}\text { R10-4 } \\
\text { R10-5 }\end{array}$ & $\begin{array}{l}\text { Valdecaballeros y } \\
\text { Monesterio } \\
\text { (Badajoz) }\end{array}$ & $\begin{array}{l}\text { Two batches } \\
\text { Controlled by Origin Designation Dehesa de Extremadura }\end{array}$ & $20+15$ \\
\hline Bellota & $\begin{array}{l}\mathrm{B} 10-1 \\
\mathrm{~B} 10-2\end{array}$ & $\begin{array}{l}\text { Valdesequera } \\
\text { (Badajoz) }\end{array}$ & $\begin{array}{l}\text { Two batches } \\
\text { - weight gain of } 66 \mathrm{~kg} \\
\text { - weight gain of } 52 \mathrm{~kg}\end{array}$ & $13+16$ \\
\hline Bellota & $\begin{array}{l}\mathrm{B} 10-3 \\
\mathrm{~B} 10-4\end{array}$ & $\begin{array}{l}\text { Valdesequera } \\
\text { (Badajoz) }\end{array}$ & $\begin{array}{l}\text { Two batches } \\
\text { - with } 60 \text { days of stay in montanera and weight gain } \\
\quad \geq 55 \mathrm{~kg} \\
\text { - with } 90 \text { days of stay in montanera and weight gain } \\
\quad \geq 79 \mathrm{~kg}\end{array}$ & $2 \times 8$ \\
\hline Bellota & $\begin{array}{l}\text { B10-5 } \\
-B 10-10\end{array}$ & $\begin{array}{l}\text { Province of } \\
\text { Badajoz }\end{array}$ & $\begin{array}{l}\text { Six batches } \\
\text { Controlled by Origin Designation Dehesa de Extremadura }\end{array}$ & $6 \times 15$ \\
\hline
\end{tabular}

the methods classified most of the samples as bellota. R08-2 had an increase in weight of $40 \mathrm{~kg}$ due to the exclusive acorn intake before slaughter without an extra contribution of compound feeds, and the classification was uneven; several methods classified this batch correctly as bellota but NIR and NEOP classified most of the samples as campo (Table 6).

None of the methods achieved a high percentage of correct prediction for the total of eight batches; with a global percentage of correct prediction ranging between $74 \%$ (isotopes) and $82 \%$ (neophytadiene), in spite of the fact that neophytadiene did not differentiate between campo and recebo categories in some batches.

In the second season, the feeding type of some batches was more complex because different kinds of recebo and batches with high fat compound feeds were added. Table 6 shows a degree of accuracy in the prediction lower than the previous season. The cebo batch CE09-1 was the only one fed with a not high fat compound feed that had a high degree of accuracy in the prediction. On the other hand, many samples of the bellota batches (B09-1 and B09-2) 
Table 4

Total number of batches and samples analyzed in the three seasons

\begin{tabular}{lcccc}
\hline & \multicolumn{3}{c}{ Seasons } & Total \\
\cline { 2 - 4 } & $\mathbf{0 8 / 0 9}$ & $\mathbf{0 9 / 1 0}$ & $\mathbf{1 0 / 1 1}$ & \\
\hline Batches & 8 & 8 & 22 & 38 \\
Bellota & 61 & 55 & 135 & 251 \\
Recebo & 40 & 50 & 74 & 164 \\
Campo & 75 & 75 & 47 & 197 \\
Cebo & 32 & 25 & 80 & 137 \\
Total & $\mathbf{2 0 8}$ & $\mathbf{2 0 5}$ & $\mathbf{3 3 6}$ & $\mathbf{7 4 9}$ \\
\hline
\end{tabular}

were improperly classified as recebo by several methods, even the B09-1 batch with a high weight gain during the montanera period.

The results obtained for the campo and recebo categories confirmed those of the previous season. The campo batches with high fat compound feeds (CA09-1 and CA09-3) had a degree of accuracy lower than the CA09-2 batch which was fed with not high fat compound feeds; despite the number of wrong classification being high in the three batches, most of them were classified as recebo and bellota. The pig origin and the formulation of high fat compound feed of the CA09-1 batch was similar to the CA08-1 batch, however the degree of accuracy in the prediction were higher than in the previous season. The use of a new kind of high fat compound feed in the C09-3 batch reduced the degree of accuracy.

The analytical methods classified a high number of samples of the recebo batch R09-1, with a weight gain in montanera according to the Quality Standard, as campo or bellota, with a majority of wrong prediction in the bellota category. However, in the R09-2 batch, a special recebo type with some supply of compound feed every day during the montanera period, the methods cataloged most of the samples in the bellota category.

The global percentages of correct predictions decreased in this season more than 20 points compared to the previous season (ranging between $42 \%$ in NIR and $62 \%$ in tocopherol or chemical sensor) and the variety of correct prediction among batches for each analytical method was also maintained.

\section{2. $2010 / 11$ season}

The main objective of the study in this season was the analyses of the accuracy degree of the analytical methods in the classification of the samples in each category. The diversity of the samples in the previous seasons was a "training" to monitor the accuracy of the predictions of each analytical method. In this season, the number and the diversity of batches were increased despite the number of samples in each batch being lower than the previous seasons. The

Table 5

Percentage of right classification predicted by the different analytical methods in the season 2008/09, according to batch and feeding type

\begin{tabular}{|c|c|c|c|c|c|c|c|c|c|}
\hline \multirow{2}{*}{\multicolumn{2}{|c|}{ Batches }} & \multicolumn{8}{|c|}{ Analytical Methods } \\
\hline & & $\begin{array}{c}1 \\
F A\end{array}$ & $\begin{array}{c}2 \\
\text { NIR } \\
\end{array}$ & $\frac{3}{\text { TOC }}$ & \begin{tabular}{|c|}
4 \\
$S Q$
\end{tabular} & $\begin{array}{c}5 \\
\text { TRIG }\end{array}$ & $\begin{array}{c}6 \\
\text { ISOT }\end{array}$ & $\begin{array}{c}7 \\
\text { NEOP }\end{array}$ & \\
\hline Cebo & CE08-1 & 100 & 100 & 100 & 93 & 100 & 100 & 100 & \\
\hline \multirow[t]{3}{*}{ Campo } & CA08-1 & 8 & 42 & 0 & 0 & 0 & 0 & 92 & \\
\hline & CA08-2 & 96 & 96 & 61 & 96 & 96 & 91 & $90^{1}$ & \\
\hline & CA08-3 & 97 & 95 & 56 & 82 & 36 & 54 & $87^{1}$ & \\
\hline \multirow[t]{2}{*}{ Recebo } & $\mathrm{R} 08-1$ & 57 & 54 & 57 & 62 & 93 & 29 & $100^{1}$ & \\
\hline & $\mathrm{R} 08-2$ & 8 & 33 & 100 & 33 & 100 & 100 & $92^{1}$ & \\
\hline \multirow[t]{2}{*}{ Bellota } & B08-1 & 100 & 68 & 100 & 100 & 100 & 100 & 86 & \\
\hline & B08-2 & 91 & 78 & 100 & 100 & 100 & 97 & 21 & \\
\hline \multicolumn{2}{|c|}{ Total accuracy } & 81 & 77 & 75 & 79 & 80 & 74 & 82 & \\
\hline \multicolumn{10}{|c|}{ Categories } \\
\hline \multicolumn{2}{|c|}{ Cebo/Campo } & 87 & 91 & 64 & 78 & 64 & 69 & 100 & Cebo \\
\hline \multicolumn{2}{|l|}{ Recebo } & 43 & 48 & 70 & 53 & 95 & 50 & 16 & Campo \\
\hline \multirow{2}{*}{\multicolumn{2}{|c|}{ Bellota }} & 95 & 73 & 100 & 100 & 100 & 98 & 97 & $R_{e c e b o}{ }^{1}$ \\
\hline & & & & & & & & 53 & Bellota \\
\hline
\end{tabular}

\footnotetext{
${ }^{1}$ Results with no discrimination between campo and recebo.
} 
Table 6

Percentage of correct classification predicted by the different analytical methods in the season 2009/10, according to the distinction of four or three categories (only cebo/campo), batches and feeding type

\begin{tabular}{|c|c|c|c|c|c|c|c|c|}
\hline & & \multicolumn{7}{|c|}{ Analytical Methods } \\
\hline & & 1 & 2 & 3 & 4 & 5 & 6 & 7 \\
\hline & & FA & NIR & TOC & SQ & TRIG & ISOT & NEOP \\
\hline \multicolumn{2}{|c|}{ Batches } & \multicolumn{7}{|c|}{ Four categories } \\
\hline Cebo & CE09-1 & & & 80 & 68 & 12 & & 100 \\
\hline \multirow[t]{3}{*}{ Campo } & CA09-1 & & & 60 & 58 & 44 & & 92 \\
\hline & CA09-2 & & & 68 & 100 & 56 & & 24 \\
\hline & CA09-3 & & & 88 & 32 & 52 & & 79 \\
\hline \multirow[t]{2}{*}{ Recebo } & R09-1 & 67 & 25 & 36 & 32 & 24 & 52 & 24 \\
\hline & R09-2 & 36 & 12 & 32 & 48 & 20 & 20 & 24 \\
\hline \multirow[t]{2}{*}{ Bellota } & B09-1 & 100 & 40 & 68 & 48 & 84 & 92 & 40 \\
\hline & B09-2 & 53 & 50 & 40 & 50 & 40 & 77 & 77 \\
\hline \multicolumn{2}{|l|}{ Total accuracy } & & & 59 & 54 & 41 & & 58 \\
\hline \multicolumn{2}{|c|}{ Batches } & \multicolumn{7}{|c|}{ Three categories (cebo/campo) } \\
\hline \multirow[t]{4}{*}{ Cebo/Campo } & CE09-1 & 100 & 100 & 92 & 100 & 100 & 100 & 100 \\
\hline & CA09-1 & 20 & 68 & 80 & 92 & 44 & 96 & 100 \\
\hline & CA09-2 & 88 & 4 & 68 & 100 & 100 & 40 & 24 \\
\hline & CA09-3 & 8 & 32 & 88 & 32 & 64 & 4 & 79 \\
\hline Total accuracy & & 59 & 42 & 62 & 62 & 59 & 60 & 59 \\
\hline \multicolumn{9}{|l|}{ Categories } \\
\hline Cebo & & & & 80 & 68 & 12 & & 100 \\
\hline Campo & & & & 72 & 64 & 51 & & 65 \\
\hline Cebo/Campo & & 54 & 51 & 82 & 81 & 77 & 60 & 76 \\
\hline Recebo & & 51 & 18 & 34 & 40 & 22 & 36 & 24 \\
\hline Bellota & & 75 & 45 & 53 & 49 & 60 & 84 & 60 \\
\hline
\end{tabular}

results are shown in Table 7 according to category of feeding instead of batches and also include the percentage of errors and their distribution over categories when only three categories are considered, grouping campo and cebo into one category.

The excellent grade of accuracy in the bellota batch exceeding $80 \%$ and $90 \%$ and the problems in conducting a correct prediction for the recebo category (ranging from $7 \%$ to $68 \%$ ) were confirmed. In fact, the methods tended to classify recebo as bellota when the batches had a high weight gain in montanera and as campo for those with a lower net weight gain.

The prediction of the analytical methods for the cebo category was disparate. Some of the analytical methods are susceptible to changes in fatty acid composition; therefore the intake of the high fat compound feeds complicates the prediction. In addition to this, if the animals feed grass in small fences, some methods can set the samples as recebo or even bellota. However, when the cebo animals have an intensive production within a stable and not high fat compound feeds are used, there are no troubles in the prediction. If the categories cebo and campo are grouped into a single category, the accuracy grade of several analytical methods can reach between 80 and $90 \%$.

\section{DISCUSSION}

The experimental design of the current study and the results obtained are completely original and they are relevant in several senses: the analytical methods are tested under the same conditions because they all use the same samples; the number of analyzed samples is large and individualized; the four categories of the Quality Standard are well represented; and, finally, there is great diversity within each category with respect to feed management. 
Table 7

Percentage of correct classification predicted by the different analytical methods in the season 2010/11, according to the distinction of four (only cebo and campo) or three categories and feeding type, and percentage and distribution of wrong classification with three categories

\begin{tabular}{|c|c|c|c|c|c|c|c|c|}
\hline & & \multicolumn{7}{|c|}{ Analytical Methods } \\
\hline & & 1 & 2 & 3 & 4 & 5 & 6 & 7 \\
\hline & & FA & NIR & TOC & SQ & TRIG & ISOT & NEOP \\
\hline Batches & \multicolumn{8}{|c|}{ Four categories } \\
\hline Cebo & & & 61 & 74 & 18 & 54 & 70 & 46 \\
\hline Campo & & & 22 & 57 & 23 & 13 & 53 & 91 \\
\hline \multirow[t]{2}{*}{ Total accuracy } & & & 60 & 74 & 50 & 43 & 69 & 61 \\
\hline & \multicolumn{8}{|c|}{ Three categories (cebo/campo) } \\
\hline Feed type & Classification & & & & & & & \\
\hline \multirow[t]{3}{*}{ Cebo/Campo } & Cebo/Campo & 66 & 94 & 98 & 43 & 72 & 81 & 95 \\
\hline & Recebo & 20 & 5 & 0 & 22 & 0 & 6 & 3 \\
\hline & Bellota & 13 & 1 & 2 & 35 & 28 & 13 & 2 \\
\hline \multirow[t]{3}{*}{ Recebo } & Cebo/Campo & 24 & 39 & 4 & 12 & 45 & 32 & 0 \\
\hline & Recebo & 32 & 33 & 68 & 16 & 7 & 33 & 8 \\
\hline & Bellota & 44 & 27 & 28 & 72 & 48 & 35 & 92 \\
\hline \multirow[t]{3}{*}{ Bellota } & Cebo/Campo & 1 & 0 & 0 & 1 & 18 & 6 & 13 \\
\hline & Recebo & 13 & 17 & 18 & 3 & 25 & 1 & 3 \\
\hline & Bellota & 87 & 83 & 82 & 96 & 57 & 93 & 84 \\
\hline \multicolumn{2}{|c|}{ Total accuracy } & 68 & 79 & 85 & 59 & 57 & 75 & 74 \\
\hline \multicolumn{2}{|c|}{ Total Observations } & 324 & 310 & 336 & 329 & 225 & 334 & 319 \\
\hline
\end{tabular}

${ }^{1}$ Isotopes results obtained by the Interprofessional Association of Iberian Pig (ASICI)

The batches of Iberian pigs did not belong to groups of animals organized according to a classical experimental design. They were selected from pigs fattened in commercial farms, except the batches of the Valdesequera experimental line. The main requirement to be included in the trial was the strict observance of the conditions for the feeding categories defined by the Quality Standard. However, the rule only establishes minimum conditions and tolerates a wide range concerning the amount of acorn consumed or the amount and composition of compound feeds. The design of the selected batches of pigs had intended to include all the diversity.

Previous works showed the competence of the analytical methods to discriminate between Iberian pigs fed in Montanera and with compound feeds. The present study confirms those results because the techniques distinguish the batches with high consumption of acorn from others fed only with commercial fodder or with low acorn ingestion. The acorn intake provides special characteristics that allow for distinguishing between the joint categories recebo/bellota from cebo/campo. As Table 8 shows, taking into account only two categories in the third season, the percentage of success in the classification of some methods is close to
$100 \%$ (tocopherol 98\%, NIR 91\%). The attempt to differentiate among four categories results in a lower accuracy, below $75 \%$.

Table 8 also contains the percentage of correct classification when the methods consider on the one hand cebo and campo (between 20\% and $68 \%$ ) and on the other hand recebo and bellota (between $45 \%$ and $77 \%$ ). Thus, cebo and campo are closely linked like the other two categories with acorn in their feeding regime. Campo requirements, unlike those of cebo (Figure 1), call for making use of the territory (maximum of 15 pigs per ha) and extends the slaughter age up to 12 months. The usual availability of pastures in the extensive system during the seasons of autumnwinter (Montanera season) deposits traces in the subcutaneous fat. This is also possible in the spring season. Some methods are able to detect such traces and to distinguish between both categories with $68 \%$ success. The batches selected were slaughtered in order to collect the samples throughout the Montanera period in which all the campo batches and also some of cebo batches had the opportunity to consume pastures and even a few acorns. The lberian pigs slaughtered in periods with no or scarce pastures should be more difficult to distinguish, although there are no results 
Table 8

Percentage of correct classification predicted by the different analytical methods in the season 2010/11 taking into account all the samples or part of them

\begin{tabular}{|c|c|c|c|c|c|c|c|c|}
\hline & & \multicolumn{7}{|c|}{ Analytical Methods } \\
\hline & & 1 & 2 & 3 & 4 & 5 & 6 & 7 \\
\hline & & $\mathrm{FA}^{1}$ & NIR & TOC & SQ & TRIG & ISOT & NEOP \\
\hline Samples & Difference between & & & & & & & \\
\hline All & 4 categories & - & 60 & 74 & 50 & 43 & 69 & 61 \\
\hline All & $\begin{array}{l}2 \text { categories: cebo/campo } \\
\text { and recebo/bellota }\end{array}$ & 82 & 91 & 98 & 75 & 74 & 84 & 65 \\
\hline $\begin{array}{l}\text { Only } \\
\text { cebo-campo }\end{array}$ & Cebo and campo & - & 47 & $\begin{array}{c}68 \\
\text { Rest } 32 \% \\
\text { ISOT } 19 \\
\text { NEOP } 11 \\
\text { Error } 2\end{array}$ & 20 & 41 & 64 & 62 \\
\hline $\begin{array}{l}\text { Only } \\
\text { recebo-bellota }\end{array}$ & Recebo and bellota & 68 & 69 & $\begin{array}{c}77 \\
\text { Rest } 23 \% \\
\text { FA } 14 \\
\text { ISOT } 7 \\
\text { Error } 2\end{array}$ & 70 & 45 & 72 & 60 \\
\hline
\end{tabular}

${ }^{1}$ FA does not distinguish between cebo and campo

to confirm this hypothesis. Similar characteristics of compound feeds for cebo and campo animals would be an impediment to differentiate between them.

The predictions results are better for recebo and bellota. Analytical methods accurately separate these categories from each other when the consumption of acorn is replaced with compound feeds, although the amount of acorn consumed and the quantity and the provided time of the compound feeds for the recebo category are essential to establish clear limits between them. A high quantity of acorn and the compound feeds containing vegetable fats with high levels of oleic fatty acids result in wrong predictions of recebo as bellota. At the same time, the bellota category from montanera with a low quantity of acorn would be predicted as recebo.

The obtained results point out the fact that the application of only one method to achieve an accurate classification of the samples into four categories is not possible. Nevertheless, a combination of several methods could be more effective. Table 8 shows the predictions made by the rest of the methods on $32 \%$ of samples with wrong classifications between cebo and campo with respect to tocopherol; this technique has more accurate global results. Isotopes would be right in $19 \%$ of them and neophytadiene in $11 \%$. Therefore, a combination of the three methods reaches a $98 \%$ success rate. The same procedure with $23 \%$ of wrong classifications of recebo and bellota results in $14 \%$ of correct classification with respect to fatty acids and $7 \%$ for isotopes. The combination of these three techniques increases the accuracy up to $98 \%$ again.
Therefore, an analysis with the tocopherol method would be adequate to discriminate samples of subcutaneous fat in two categories (cebo/campo y recebo/bellota) with $98 \%$ success. Adding the fatty acid quantification, isotopes and neophytadiene make it possible to distinguish among the four categories with $98 \%$ accuracy.

As pointed out previously, all the analyses and the prediction exercises took place with individual samples. The number of erroneous classifications within batches never exceeds $25 \%$ of the animals, which means that a unique analysis of the fat samples in each batch (as required by the official protocol: BOE, 2007) would be even more successful.

\section{CONCLUSION}

Several analytical methods have demonstrated their capacity to distinguish between feeding regimes based on the consumption of acorn and pastures from regimes based on compound feeds. The animal traceability on farms should be and additional tool for this task. The differentiation results between the categories of recebo and bellota applying only one method, although hopeful, are not definite. A certain classification of animals with a mixed regime of acorn and compound feed demands more research taking the issue into account in the compound feed supply. An analysis of a high number of batches, more variability with respect to the feeding system and the consideration of the batch as an experimental unit could facilitate a solution to the problem. Finally, the application of two or three analytical methods increases the 
accuracy to distinguish among problematic or doubtful feeding regimes, reaching reliability of up to $100 \%$ for the four categories.

\section{ACKNOWLEDGEMENTS}

The authors wish to express their gratitude to the "Centro de Investigación La OrdenValdesequera" that made possible the control of the animals of many batches used in this study, especially to Dolores Ayuso and Mercedes Izquierdo. The acknowledgment must be extended to the selfless collaboration of a high number of pig breeders, product industries, slaughterhouses and to the Origin Designation Dehesa de Extremadura and Jamón de los Pedroches. This research was supported by the project INIA RTA08-26 and the agreement INIA-MAGRAMA CC08-31.

\section{REFERENCES}

BOE, Boletín Oficial del Estado. 1998. ORDEN de 22 de julio de 1998 por la que se homologa el contratotipo de compraventa de cerdos ibéricos cebados con destino a su sacrificio y elaboración, que regirá hasta el 31 de agosto de 1999. Num. 191, pp. 2595625958.

BOE, Boletín Oficial del Estado. 2001. Real Decreto $1083 / 2001$, de 5 de octubre, por el que se aprueba la norma de calidad para el jamón ibérico, paleta ibérica y caña de lomo ibérico elaborados en España. Num. 247, pp. 37830-37833.

BOE, Boletín Oficial del Estado. 2004. Orden PRE/3844/2004, de 18 de noviembre, por la que se establecen los métodos oficiales de toma de muestras en canales de cerdos ibéricos y el método de análisis para la determinación de la composición de ácidos grasos de los lípidos totales del tejido adiposo subcutáneo de cerdos ibéricos. Num. 283, pp. 38770-38779.

BOE, Boletín Oficial del Estado. 2007. Real Decreto 1469/2007, de 2 de noviembre, por el que se aprueba la norma de calidad para la carne, el jamón, la paleta y la caña de lomo ibéricos. Num. 264, pp. 4508745104.

Carrasco A, Martín C, Lizaso J, Mallo JJ, López C, Gómez E, Rodríguez A, de Mercado E, Sanz E. 2007. El sensor químico como herramienta para la trazabilidad de los alimentos: aplicación en productos del cerdo Ibérico. Libro de Ponencias del IV Congreso Mundial del Jamón. Salamanca 2007, pp. 407-408.

De Pedro E, Garrido A, Lobo A, Dardenne P, Murray I. 1995. Objective classification of Iberian pig carcasses: GC versus NIR. GD Batten, PC Flinn, LA Welsh and AB Blakeney (Eds.). Leaping ahead with near infrared spectroscopy. NIR Spectroscopy Group. Royal Australian Chemistry Institute. Melbourne, Australia, pp. 291-295.
Flores J, Biron C, Izquierdo L, Nieto E. 1988. Characterization of green hams from Iberian pigs by fast analysis of subcutaneous fat. Meat Sci. 23, 253262.

Gamero-Pasadas A, Viera-Alcaide I, Rios JJ, GracianiConstante E, Vicario IM, León-Camacho M.2006. Characterization and quantification of the hydrocarbons fraction of the subcutaneous fresh fat of Iberian pig by off-line combination of high performance liquid chromatography and gas chromatography. J. Chromatogr. A. 1123, 82-91.

García-Olmo J, Garrido-Varo A, De Pedro E. 2009. Classification on real farm conditions Iberian pigs according to the feeding regime with multivariate models developed by using fatty acids composition of NIR spectral data. Grasas Aceites 60, 233-237.

González-Martín I, González-Pérez C, Hernández Méndez J, Sánchez González C. 2001.Differentiation of dietary regime of Iberian swine by means of isotopic analysis of carbon and sulphur in hepatic tissue. Meat Sci. 58, 25-30.

Ministerio de Agricultura, Alimentación y Medio Ambiente. Registro Informático del Cerdo Ibérico: http://www.magrama.gob.es/app/riber/Publico/ BuscadorCensoAnimales.aspx.

Ordóñez JA, López MO, Hierro E, Cambero MI, De la Hoz L. 1996. Efecto de la dieta de Cerdos Ibéricos sobre la composición en ácidos grasos del tejido adiposo y muscular. Food Sci. Technol. Int. 2, 383-390.

Osorio E, Montero de Espinosa V, Sánchez JJ, Lozano M. 1991. Influencia de la alimentación sobre la composición en ácidos grasos del tejido adiposo de Cerdos Ibéricos. Rev. Agroquím. Tecnol. Alimentos 31, 558-564.

Recio C. 2007. GC-C-IRMS de FAMEs y otras técnicas isotópicas para determinar la alimentación del cerdo Ibérico: un paso más allá. Libro de Ponencias del IV Congreso Mundial del Jamón. Salamanca 2007, pp. 59-63.

Rey Al, Daza A, López-Carrasco C, López-Bote CJ. 2006. Feeding Iberian pigs with acorns and grass in either free-range or confinement affects the carcass characteristics and fatty acids and tocopherols accumulation in L. dorsi muscle and backfat. Meat Sci. 73 66-74.

Rey Al, Isabel B, Cava R, López-Bote CJ. 1998. Dietary acorns provide a source of gamma-tocopherol to pigs raised extensively. Canadian J. Animal Sci. 78, 441443.

Tejeda J F, Antequera T, Ruiz J, Cava R, Ventanas J, García C. 1999. Unsaponifiable fraction and n-alkane profile of subcutaneous fat from Iberian ham. Food Sci. Technol. Inter. 5, 229-233.

Viera Alcaide I, Vicario IM, Escudero-Gilete ML, Graciani Constante E, León-Camacho M. 2008. A multivariate study of the triacylglycerols composition of the subcutaneous adipose tissue of Iberian pig in relation to the fattening diet and genotype. Grasas Aceites 59, 327-336.

Recibido: $16 / 10 / 12$ Aceptado: 26/1/13 